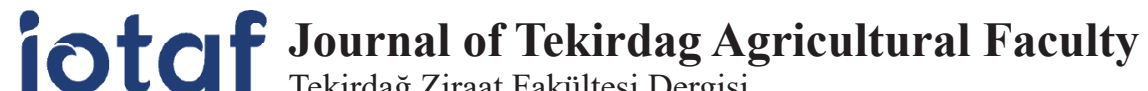 \\ Tekirdağ Ziraat Fakültesi Dergisi
}

Mayıs/May 2019, 16(2)

\section{Bazı Bitki Ekstraktlarının Pseudomonas syringae pv. tomato'nun Neden olduğu Domates Bakteriyel Benek Hastalığına Antibakteriyel Etkisi}

\author{
Antibacterial Effects of Some Plant Extracts against Tomato Bacterial Speck Disease Caused \\ by Pseudomonas syringae pv. tomato
}

\section{Feray KARABÜYÜK ${ }^{1,2}$, Yeșim AYSAN ${ }^{1}$}

\section{$\ddot{\mathbf{O}} \mathbf{z}$}

Pseudomonas syringae pv. tomato (Pst)'nun neden olduğu Bakteriyel Benek Hastalığ domatesin en önemli tohum kaynaklı bakteriyel hastalığıdır. Bu çalışmada, yirmi dokuz bitki ekstraktının antibakteriyel etkileri in vitro ve in vivo'da araştırılmıştır. In vitro'da, Allium sativum $3 \mathrm{~mm}$, Coriandrum sativum $13 \mathrm{~mm}$, Eucalyptus camaldulensis $13.6 \mathrm{~mm}$ Pst'ye antibakteriyel etki göstermiştir. Pst'ye karşı Minimum Engelleme Konstantrasyonu değerleri (MIC) Allium sativum için $4.25 \mu$ l/ml, Eucalyptus camaldulensis için $3.75 \mu \mathrm{l} / \mathrm{ml}$, Origanum onites için ise $>128 \mu \mathrm{l} / \mathrm{ml}$ olarak belirlenmiştir. Allium sativum, Coriandrum sativum, Eucalyptus camaldulensis, Origanum onites, Origanum vulgare subs. hirtum ve Zingiber officinale bitki ekstraktları tohuma uygulanmış ve Pst'nin neden olduğu hastalık \%8.8-100 oranında engellenmiştir. Çalışmada, A. sativum ve O. onites en başarılı tohum uygulaması olarak saptanmıştır. Bitki ekstraktları domates tohumlarının çimlenmesine herhangi bir olumsuz etki yapmamıştır. Saksı çalışmalarında, Allium sativum, Eucalyptus camaldulensis, Origanum onites, Zingiber officinale ekstraktları yeşil aksama püskürtüldüğünde $P$ st'nin neden olduğu hastalık \%96-99, ekstraktlar köke uygulandığında \%80-100 oranında baskılanmıştır. Köke Allium sativum ekstraktı uygulamak domates fidelerinde toksik olmuştur. Sonuç olarak, bitki ekstraktları domates bakteriyel hastalıklarının mücadelesinde yeni pestisitlerin geliştirilmesi açısından ümit vaat etmektedir.

Anahtar Kelimeler: Domates, Bitki Ekstraktı, Antibakteriyel etki, Tohum uygulamaları, Yeşil aksam uygulamaları

\begin{abstract}
Bacterial speck disease caused by Pseudomonas syringae pv. tomato (Pst) is the most important seed-borne bacterial disease of tomato. In this study, the antibacterial activities of aqueous twenty-nine plant extracts were investigated in vitro and in vivo conditions. In in vitro experiments, extracts of Allium sativum, Coriandrum sativum, Eucalyptus camaldulensis inhibited Pst growth with the inhibition zones $3 \mathrm{~mm}, 13 \mathrm{~mm}$ and $13.6 \mathrm{~mm}$, respectively. Minimum Inhibition Concentrations (MIC) values against Pst determination were Eucalyptus camaldulensis $3.75 \mu \mathrm{l} / \mathrm{ml}$, Allium sativum $4.25 \mu \mathrm{l} / \mathrm{ml}$, and Origanum onites $>128 \mu \mathrm{l} / \mathrm{ml}$. The effects of Allium sativum, Coriandrum sativum, Eucalyptus camaldulensis, Origanum onites, Origanum vulgare subs. hirtum and Zingiber officinale extracts on disease incidence and severity caused by Pst recorded 8.8-100\% ratios as seed treatments. The most successful seed treatments were Allium sativum and Origanum onites extracts. Additionally, no negative effect on seed germination and emergence were recorded for the tested plant extracts as seed treatments. In pot experiments, foliar spraying of Allium sativum, Eucalyptus camaldulensis, Origanum onites, Zingiber officinale extracts were reduced the disease incidence from $96 \%$ to $99 \%$ ratios, whereas the disease incidence was inhibited as $80-100 \%$ ratios by root dipping. Root dipping applications of Allium sativum extract were toxic on tomato plants in both experiments for Pst. As a result, plant extracts are promising for the development of new pesticides in the control of bacterial diseases of tomatoes.
\end{abstract}

Keywords:Tomato, plant extracts, antibacterial effect, seed treatments, foliage applications

\footnotetext{
1*Sorumlu Yazar/Corresponding Author: Feray Karabüyük, Çukurova Üniversitesi, İmamoğlu Meslek Yüksekokulu, 01700, Adana, E mail: feraykrbyk@gmail.com (D) OrcID: 0000000248842122

2 Yeşim Aysan, Çukurova Üniversitesi, Ziraat Fakültesi, Bitki Koruma Bölümü, 01330, Adana, E-mail: aysanys@gmail.com (iD) OrcID: 0000000326475111
}

Atıf/Citation: Karabüyük, F., Aysan, Y. Bazı bitki ekstraktlarının Pseudomonas syringae pv. tomato'nun neden olduğu domates bakteriyel benek hastalığına antibakteriyel etkisi . Tekirdă̆ Ziraat Fakültesi Dergisi, 16(2), 231-243.

CBu çalışma Tekirdağ Namık Kemal Üniversitesi tarafından Creative Commons Lisansı (https://creativecommons.org/licenses/by-nc/4.0/) kapsamında yayınlanmıştır. Tekirdağ 2019 


\section{Extendend Summary}

Tomato (Solanum lycopersicum L.) is the most cultivated plant in the world and in our country (Anonim, 2017). Tomato yield and quality are adversely affected by diseases caused by fungal, bacterial and viral pathogens (Arshad et al., 2014). Bacterial Speck Disease caused by Pseudomonas syringae pv. tomato (Pst) significantly affect crop yield and quality of tomatoes. Pst is one of the most important seed-borne bacterial diseases of tomato (Miller and Jones, 2014). The disease is a necessity to develop different strategies in disease management due to the cost of synthetic chemicals used in the disease struggle, the problem of phytotoxicity in different plants, the problem of resistance to applied chemicals, the negative effects of these chemicals on human and environmental health and the tendency of consumers to organic products (Mc Manus ve ark., 2002; Mbega ve ark., 2011). Due to these reasons, interest in antibacterial compounds derived from natural sources has gained importance in recent years. In this study, the antibacterial activities of aqueous extracts from twenty-nine medical and aromatic plants were investigated in vitro and in vivo conditions. The antibacterial activity of plant extracts in in vitro conditions was determined by the paper disc method and only three of the 29 extracts (Allium sativum, Coriandrum sativum and Eucalyptus camaldulensis) have shown inhibitory effect. As a result in in vitro, among medical and aromatic plant extracts, Allium sativum, Coriandrum sativum and Eucalyptus camaldulensis has shown inhibitory effect on Pst giving mean inhibition zones of $3 \mathrm{~mm}, 13.0 \mathrm{~mm}$ and $13.6 \mathrm{~mm}$, respectively. Another in vitro experience, the Minimum Inhibition Concentrations, (MIC) of plant extracts inhibited the development of the pathogen were also determined. MIC values for Allium sativum, Eucalyptus camaldulensis and Origanum onites extracts used against Pst were determined as $4.25 \mu \mathrm{l} / \mathrm{ml}, 3.75 \mu \mathrm{l} / \mathrm{ml}$ and $>128 \mu \mathrm{l} / \mathrm{ml}$, respectively. The selected six plant extracts (Allium sativum, Eucalyptus camaldulensis, Coriandrum sativum, Origanum onites, Origanum vulgare subsp. hirtum and Zingiber officinale) were applied to the seeds inoculated with pathogen and their efficacies on seed germination were determined. On request, all seed applications were found to be different and effective than the positive control application. The effects of Allium sativum, Coriandrum sativum, Eucalyptus camaldulensis, Origanum onites, Origanum vulgare subsp. hirtum and Zingiber officinale extracts on disease incidence and severity recorded at the ratios of $8.8-100 \%$ as seed treatments. In the disease severity of an average decrease of $21.5-100 \%$ was determined. Additionally, seed treatments did not reduce seed germination. In pot experiments, spraying of Allium sativum, Eucalyptus camaldulensis, Origanum onites, Zingiber officinale extracts were reduced the disease incidence at the ratios of $96-99 \%$. The application of plant extracts before or after pathogen contamination did not make any difference in the effect of the disease. When the seedlings were root dipping in plant extracts before planting, plant extracts except Allium sativum reduced the disease severity by $80.1-100 \%$. However, Allium sativum extract was toxic totomato roots. As a result of the study, the antibacterial effects of Allium sativum, Eucalyptus camaldulensis, Origanum onites and Zingiber officinale extracts on bacterial diseases of tomatoes have been demonstrated. 
Pseudomonas syringae pv. tomato (Pst)'nun neden olduğu bakteriyel benek hastalığı domates yetiştiriciliğinde sorun olan önemli bakteriyel hastalıklar içerisinde yer almaktadır (Agrawal ve ark., 2012; Jones ve ark., 2014). Bakteriyel benek hastalığı ülkemizde domates yetiştirilen alanlarda görülen en yaygın bakteriyel hastalıklardan biridir.

Etmenin neden olduğu hastalık, domates bitkisinin gövde, yaprak, sap, çiçek ve meyve sapları gibi tüm toprak üstü aksamlarında kahverengiden siyaha kadar değişen renkte lekeler, meyvelerde ise çapları 1 mm'yi geçmeyen yüzeysel kabarcıklar şeklinde belirtilere neden olmaktadır. Bakteri bitkinin içinde sistemik ilerlemese de tohuma yerleşir ve farklı alanlara enfekteli tohum veya fide kullanımıyla yayılır (Aysan ve Saygıl1, 2008; Miller ve Jones, 2014). Bu hastalık en önemli zararını tohum kökenli enfeksiyonlardan dolayı fide döneminde yapar. Tohum kabuğunda bulunan Pst, tohumun çimlenmesiyle ilk gelişen kotiledon yapraklarda lekeler oluşturur ve ticari fideliklerde gerekli önlemler alınmadığı takdirde ciddi fide kayıplarıyla karşılaşılır. Benzer durum, ülkemizde 2004 yılında Akdeniz Bölgesi'ndeki ticari fideliklerde yaşanmıştır. Domates Bakteriyel Benek Hastalığı epidemisi sonucu binlerce domates fỉdesi imha edilmek zorunda kalınmıştır (Aysan ve ark., 2004; Basım ve ark., 2004).

Bitkisel üretimde başlangıç materyali olarak kullanılan tohum, yüksek verim ve kaliteli ürün elde edilmesinde doğrudan etkilidir. Ancak tohum kaynaklı hastalıklar, ürün verimini ve kalitesini ciddi şekilde etkileyebilmektedir. Bitki bakteriyel hastalıklarıyla mücadelede ilk şart hastalıksız tohum/fideyle üretime başlamaktır. Pst'nin neden olduğu hastalığın ilk inokulum kaynağı patojen bakteriyle bulaşık tohum veya fidelerdir. Tohumla taşınan hastalıklarla mücadelede en etkili yöntemlerden biri tohum üretimi sırasında bakteriyel inokulumun bulaşmasını engellemektir. Ticari fideliklerde bakteri bulaşıklığg varsa etkili tohum uygulamalarını ve yeşil aksam ilaçlamalarını kullanmak önemlidir. Diğer bir mücadele stratejisi de bitkinin hastalıklara karşı dayanıklılığını artırmaktır. Üretim esnasında bu hastalıklarla karşılaşıldığında da bakırlı preparatlar veya bitki aktivatörleri yeşil aksama püskürtülerek uygulanmalıdır (Soykan ve Aysan, 2011; Çetinkaya-Yıldız ve ark., 2014; Farimaz ve ark., 2014).

Tüketicilerin son yıllarda bilinçlenmesiyle üreticiler de bitkisel üretimde insan ve çevre sağlı̆̆ına olumsuz etkisi olan kimyasalları kullanmak istememektedirler. Bu nedenle ekonomik öneme sahip bitki hastalık ve zararlılarına karşı, yeni mücadele stratejileri geliştirmek, bitkide hastalıklara dayanıklılığı uyaran yeni preparatlar bulmak, hatta insan sağlığına ve çevreye dost yeni kimyasal bileşiklerin elde edilmesine yönelik araştırmalarda artış olmuştur (Mc Manus ve ark., 2002; Mbega ve ark., 2011).

Hastalık etmeni bakterilerin mücadelesinde tarımsal antibiyotiklerin kullanımının ülkemizde ve pek çok ülkede yasak olması nedeniyle, doğal antibiyotik olarak adlandırılan tıbbi ve aromatik bitkilerden elde edilen antimikrobiyal maddelerin kullanımıyla ilgili araştırmalara olan ilgi son yıllarda artmıştır. Bu araştırmalardaki artışın nedenlerinden bazıları; doğada kolay bulunmaları, ucuz olmaları, doğaya toksik madde yaymamaları, kısa zamanda dekompoze olarak toprak ve su kirliliğine yol açmamaları, insan sağlığını tehdit edecek uzun süreli kalıntılar oluşturmamaları ve hastalık etmenlerine spesifik olmalarıdır (Erlen, 2000; Mbega ve ark., 2011). Bu bitkiler sekonder metabolitler bakımından zenginlerdir ve bulundukları bitkilerin yaşadıkları çevredeki biyotik ve abiyotik stres faktörlerine karşı savunma sistemlerini oluşturmalarıdır. Sekonder metabolitler çoğunlukla antifungal, antibakteriyel, antivirütik ve antioksidan etkilidir. Bu nedenle, bitkilerde hastalık ve zararlılara karşı savunmanın yanında, stres ve olumsuz çevre faktörlerine karşı korunma gibi önemli görevleri de bulunmaktadır (Baydar, 2009).

$\mathrm{Bu}$ çalışma ile, domates yetiştiriciliğinde sorun olan Pst'nin neden olduğu Domates Bakteriyel Benek Hastalığının mücadelesinde bitki ekstraktlarının kullanım olanakları ve entegre mücadele programlarına dahil edilme olanakları araştırılmıştır.

\section{Materyal}

\section{Materyal ve Yöntem}

\section{Hastalık Etmeni İzolatlar}

Çukurova Üniversitesi Ziraat Fakültesi Bitki Koruma Bölümü bakteriyoloji laboratuvarı kültür koleksiyonlarında bulunan YA-581 kodlu Pst izolatı çalışmada kullanılmıştır. YA-581 kodlu izolat Adana ili Karataş ilçesinden (Karabüyük ve ark., 2014) hasta domates bitkilerinden izole edilmiştir.

\section{Domates Tohum ve Fideleri}

Tohum uygulamalarında, tohuma herhangi bir uygulama yapılmamış ilaçsız tohumla çalışma yapılmıştır. Bu amaçla PTK 102 çeşidi domates tohumları kullanılmıştır. Saksı çalışmalarında Pst ile kurulan denemelerde baharlık bir domates çeşidi olan İskender F1 çeşidi kullanılmıştır. 


\section{Tıbbi ve Aromatik Bitkiler}

Denemelerde 29 farklı tıbbi ve aromatik bitki türünden elde edilen ekstraktlar kullanılmıştır. Bu bitkiler, (1) Çukurova Üniversitesi Karaisalı Meslek Yüksekokulu Tıbbi ve Aromatik Bitki Koleksiyon Bahçesi, (2) Ali Nihat GÖKYİĞİT Botanik Bahçesi, (3) Mustafa Kemal Üniversitesi Ziraat Fakültesi Tarla Bitkileri Bölümü Tıbbi ve Aromatik Bitkiler Koleksiyon Bahçesi, (4) Adana’nın Sarıçam ve Karaisalı ilçeleri doğal florası ve (5) ticari olarak satış yapan marketlerden temin edilmiştir (Tablo 1.).

Tablo 1. Denemelerde kullanılan tıbbi ve aromatik bitki türleri

Table 1. Types of medicinal and aromatic plants used in experiments

\begin{tabular}{|c|c|c|c|}
\hline Bitki Türü & Yerel Ad 1 & Temin edildiği Yer & Kullanılan Bitki Aksamı \\
\hline Aloe vera $\mathrm{L}$. & Aloevera & \multirow{9}{*}{$\begin{array}{l}\text { Ç.Ü. Karaisalı Meslek } \\
\text { Yüksekokulu } \\
\text { Koleksiyon Parselleri }\end{array}$} & Yeşil aksam \\
\hline Calendula officinalis $\mathrm{L}$. & Tıbbi nergis & & Çiçek \\
\hline Coriandrum sativum L. & Kişniş & & Tohum/ Meyve \\
\hline Echinacea purpurea L. & Ekinezya & & Çiçek \\
\hline Lavandula angustifolia $\mathrm{L}$. & Lavanta & & Çiçek \\
\hline Matricaria chamomilla $\mathrm{L}$. & Tibbi papatya & & Çiçek \\
\hline Mentha piperita $\mathrm{L}$. & Tibbi nane & & Yaprak \\
\hline Rosmarinus officinalis L. & Biberiye & & Çiçekli Dallar \\
\hline Salvia officinalis L. & Tıbbi Adaçayı & & Yaprak \\
\hline $\begin{array}{l}\text { Origanum onites L. } \\
\text { Origanum vulgare subsp. hirtum (Link) Ietsw }\end{array}$ & $\begin{array}{l}\text { İzmir Kekiği } \\
\text { İstanbul Kekiği }\end{array}$ & $\begin{array}{c}\text { Ç.Ü. Ali Nihat GÖKYİĞİT } \\
\text { Botanik Bahçesi }\end{array}$ & Toprak Üstü Aksam \\
\hline $\begin{array}{l}\text { Thymbra spicata L. subsp. spicata } \\
\text { Thymus vulgaris L. }\end{array}$ & $\begin{array}{c}\text { Karabaş Kekik } \\
\text { Adi kekik }\end{array}$ & $\begin{array}{c}\text { Mustafa Kemal Üniversitesi, } \\
\text { Ziraat Fakültesi, Tarla } \\
\text { Bitkileri Bölümü, } \\
\text { Tibbi-Aromatik Bitkiler } \\
\text { Koleksiyon Bahçesi } \\
\end{array}$ & Yeşil aksam \\
\hline Capparis ovata Desf. & Kapari & \multirow{4}{*}{ Karaisalı/ADANA } & Yeşil aksam \\
\hline Hypericum perforatum L. & Kantaron & & Yeşil aksam \\
\hline Myrtus communis L. & Mersin & & Yeşil aksam \\
\hline Sinapsis nigra $\mathrm{L}$. & Hardal & & Yeşil aksam \\
\hline Eucalyptus camaldulensis Dehnh. & Okaliptüs & \multirow{2}{*}{ Sarıçam/ADANA } & \multirow{2}{*}{ Yeşil aksam } \\
\hline Nerium oleander L. & Zakkum & & \\
\hline Allium sativum $\mathrm{L}$. & Sarımsak & \multirow{10}{*}{ Market } & Soğan \\
\hline Allium cepa $\mathrm{L}$. & Soğan & & Soğan \\
\hline Anethum graveolens $\mathrm{L}$. & Dereotu & & Yeşil aksam \\
\hline Cuminum cyminum $\mathrm{L}$. & Kimyon & & Tohum \\
\hline Foeniculum vulgare Mill. & Rezene & & Tohum \\
\hline Ocimum basilicum $\mathrm{L}$. & Fesleğen & & Yeşil aksam \\
\hline Pimpinella anisum $\mathrm{L}$. & Anason & & Tohum \\
\hline Raphanus sativus L. & Antep Turpu & & Yumru \\
\hline Syzygium aromaticum (L.) Merr. \& L.M.Perry. & Karanfil & & Tohum \\
\hline Zingiber officinale L. & Zencefil & & Yumru \\
\hline
\end{tabular}




\section{Besi Yerleri}

Çalışmada katı besi yeri olarak King B (KB) (Proteose peptone 20.0 g/lt; $\mathrm{K}_{2} \mathrm{HPO}_{4} 7 \mathrm{H}_{2} \mathrm{O} 1.5 \mathrm{~g} / \mathrm{lt} ; \mathrm{MgSO}_{4} 7 \mathrm{H}_{2} \mathrm{O}$ $1.5 \mathrm{~g} / \mathrm{lt}$; agar $15 \mathrm{~g} / \mathrm{lt}$; Glycerol $10.0 \mathrm{ml} / \mathrm{lt}$ ) ve sivı besi yeri olarak Nutrient Broth (NB) (Merck 1.07228.0500; $8 \mathrm{gr} /$ 1t) kullanılmıştır (Lelliott ve Stead,1987).

\section{İklim Odasının Özellikleri}

Çukurova Üniversitesi, Ziraat Fakültesi, Bitki Koruma Bölümünde bulunan, 16:8 saat aydınlatmalı, \%75 nem, $25 \pm 2^{\circ} \mathrm{C}$ sıcaklık, klima ile 1sıtılan/soğutulan iklim odası koşullarında tohum denemeleri yapılmıştır.

\section{Sera Özellikleri}

Çukurova Üniversitesi, Ziraat Fakültesi, Bitki Koruma Bölümü Deneme ve Araştırma parsellerinde bulunan yüksek tip ısıtmasız cam serada saksı denemeleri yapılmıştır.

\section{Toprak ve plastik küvet-saksı özellikleri}

İklim odasında yapılan tohum denemelerinde ticari olarak satılan steril torf, plastik küvetler (36 x 23x $8 \mathrm{~cm}$ boy, en, yükseklik), sera denemelerinde ise çiftlik gübresi karıştırılarak doğal toprak ve plastik saksılar ( 8 x 8 x 20 cm boy, en, yükseklik) kullanılmıştır.

\section{Yöntem}

\section{Bitki Ekstraktlarının Hazırlanması}

Tıbbi ve aromatik bitkilerin farklı aksamlarından 100 gr bitki parçası $100 \mathrm{ml}$ distile su içerisinde elektrikli parçalayıcıda parçalanarak ekstrakte edilmiştir. Tohumları kullanılan bitkiler çok zor parçalandıkları için, bir gece önceden 1:1 oranında steril su içerisinde bekletilerek ertesi gün parçalanmıştır. Homojenize edilen bitki ekstraktları tülbentten süzülerek iri parçalardan ayrılmıştır. Geriye kalan sulu ekstrakt 6.500 rpm'de 15 dakika santrifüj edilerek üstteki sıvı (süpernatant) alınmış altta kalan pellet atılmıştır. In vivo tohum ve saksı denemelerinde hazırlanan ekstraktlar santrifüj aşamasından hemen sonra kullanılmıştır. In vitro petri denemelerinde ise hazırlanan ekstraktlar filtreden geçirilerek soğuk sterilizasyon yöntemiyle sterilize edilmiştir. Bu amaçla hazırlanan ekstraktlar ilk önce $45 \mu \mathrm{m}$ por'luk filtre içeren vakumlu holder'den geçirilmiş (Kozak ve ark., 2014), ardından Milipore marka 0.22 $\mu \mathrm{m}$ por'luk filtreden geçirilerek (Mirik ve ark., 2002; Balestra ve ark., 2009) steril edilmiştir. Çalışmada her zaman taze olarak hazırlanan ekstraktlar kullanılmıştır.

\section{Farklı Bitki Ekstraktlarının Pseudomonas syringae pv. tomato'ya Antibakteriyel Etkisi}

Yirmi dokuz farklı tıbbı ve aromatik bitki ekstraktının, domates bakteriyel patojenlerinden Pst'ye antibakteriyel etkisi in vitro'da kağıt disk yöntemine göre belirlenmiştir (Mangama ve Sreeramulu, 1981).

Spektrofotometrede $\mathrm{A}_{600}: 0.2$ hazırlanan patojen bakteri süspansiyonu seyreltilerek son popülasyon olarak yaklaşık $10^{6}$ hücre/ml'ye ayarlanmıştır. Bu süspansiyondan $100 \mu \mathrm{l}$ alınarak KB besi yeri içeren petrilere patojen üç tekrarlı olarak bagetle yayılmıştır. Petriler steril kabinde yaklaşık 1 saat bekletildikten sonra, $1 \mathrm{~cm}$ çapında yuvarlak 3 adet filtre kağıdı 120 derece açıyla birbirinden eşit uzaklıkta olacak şekilde her petriye yerleştirilmiştir. Sterilize edilmiş bitki ekstraktlarından $20 \mu 1$ alınıp kağıt diskler üzerine damlatılmıştır. Çalışmada negatif kontrol olarak steril su, pozitif kontrol olarak ise $P s t^{\prime}$ ye etkili bir antibiyotik olan Streptomisin sülfat $(100 \mathrm{mg} / \mathrm{ml})$ kullanılmıştır. Uygulama yapılmış petriler $25^{\circ} \mathrm{C}^{\prime}$ de 24 saat inkübatörde bekletilmiştir. İnkübasyondan sonra kağıt diskler etrafında oluşan engelleme zonunun çapı (mm) ölçülerek kaydedilmiştir.

Farklı Bitki Ekstraktlarını Pseudomonas syringae pv. tomato'yu Minimum Engelleme Konsantrasyonlarının Belirlenmesi

Kağıt disk yöntemiyle etkili bulunan bitki ekstraktlarının (A. sativum, C. sativum, E. camaldulensis), Pst'yi engelleyen minimum konsantrasyon (Minimum Inhibition Concentrations, MIC) değeri tüp dilüsyon yöntemine göre belirlenmiştir (Kotan ve ark., 2007; Kamba ve ark., 2010; Murthy ve ark., 2015; Anonim, 2018). Çalışmaya ayrıca antibakteriyel etkisi saptanmasa da $O$. onites ekstraktı da dahil edilmiştir.

Tüp dilüsyon yönteminde, NB besi yeri içeren cam deney tüplere $1 \mathrm{ml}$ patojen bakterinin (Pst) belli popülasyondaki (yaklaşık $10^{6}$ hücre/ml) inokulumu eklenmiştir. Daha sonra taze hazırlanmış bitki ekstraktlarının farklı konsantrasyonları $(0.125 \mu \mathrm{l} / \mathrm{ml}, 0.25 \mu \mathrm{l} / \mathrm{ml}, 0.5 \mu 1 / \mathrm{ml}, 1 \mu \mathrm{l} / \mathrm{ml}, 2 \mu \mathrm{l} / \mathrm{ml}, 4 \mu 1 / \mathrm{ml}, 8 \mu 1 / \mathrm{ml}, 16 \mu 1 / \mathrm{ml}, 32$ $\mu \mathrm{l} / \mathrm{ml}, 64 \mu \mathrm{l} / \mathrm{ml}$ ve $128 \mu \mathrm{l} / \mathrm{ml}$ ) her bir tüpe belirtilen oranlarda ilave edilmiştir. Ayrıca bitki ekstraktı içermeyen, bakteri üremesinin göstergesi olan kontrol tüpüne de sadece patojen bakteri eklenmiştir. Patojen bakteri inoküle edilmemiş, sadece sıvı besi yeri içeren bir tüp de besi yeri kontrolü olarak kullanılmıştır. Tüpler $25^{\circ} \mathrm{C}$ 'de bir gün inkübe edildikten sonra bakteri üremesini gösteren bulanıklık yönünden incelenmiştir. Her bir tüpten $100 \mu 1$ alınarak KB içeren petrilere üç tekrarlı olarak bagetle yayılmıştır. Uygulama yapılmış petriler $25^{\circ} \mathrm{C}^{\prime} \mathrm{de} 24$ saat inkübe edilmiştir. Bakterinin üremesini önleyen, gözle görünür bir bulanıklığın ve besi yerinde gelişimin olmadığı 
en düşük bitki ekstraktı konsantrasyonu, MIC değeri olarak belirlenmiştir.

\section{Domates Tohumlarının Pseudomonas syringae pv. tomato ile Bulaştırılması}

YA-581 kodlu Pst izolatı KB besi yerinde $25^{\circ} \mathrm{C}$ 'deki inkübatörde 24 saat süreyle geliştirilmiștir. Gelişen bakteriden saf suyla spektrofotometre yardımıyla $\mathrm{A}_{600}: 0.2$ ölçüm değerinde bir süspansiyon hazırlanmıştır. Hazırlanan süspansiyona (yaklaşık 2.9x10 hücre/ml) domates tohumları batırılmış ve 30 dakika süreyle 150 rpm hızda oda sıcaklığında çalkalanarak patojen bakteriyle bulaştııılmıştır. Bulaştırma işleminden sonra süzgeçle süzülen tohumlar 20x20 ebatlarında tahta çerçeveler üzerine örtülen tülbentlere yayılarak bir gece boyunca kurumaya bırakılmıştır. Negatif kontrol uygulamasında sağlıklı domates tohumları aynı yöntemle sadece saf suya daldırılmış ve ardından ekimi yapılmıştır.

\section{Farklı Bitki Ekstraktlarının Tohum Uygulaması Olarak Domates Bakteriyel Benek Hastalığına Etkisi}

Çalışmanın bu bölümünde A. sativum, C. sativum, E. camaldulensis, $O$. onites, $O$. vulgare subsp. hirtum ve $Z$. officinale bitkilerinden elde edilen altı farklı bitki ekstraktı kullanılmıştır.

\section{Patojenle Bulaşık Tohumlara Bitki Ekstraktlarının Uygulanması}

Yapay olarak Pst ile bulaştırılmış domates tohumları, erlen içerisinde bulunan 6 farklı bitkiden hazırlanan ekstraktlara 30 dakika daldırılmıştır. Bu süre sonunda süzgeçle süzülen uygulama görmüş tohumlar torfla dolu plastik küvetlere ekilmiştir. Küvetler daha önce koşulları belirtilen iklim odasına yerleştirilmiştir. Uygulama görmüş tohumlardan gelişen fideler hastalık yönünden incelenerek uygulamaların tohum kökenli olan bakteriyel benek hastalığı çıkışına ve şiddetine etkisi araştırılmıştır (van der Wolf ve ark., 2008; Dadasoglu ve ark., 2011; Kotan ve ark., 2013; Baştaş, 2015). Çalışma, özellikleri daha önce belirtilen iklim odası koşullarında yapılmıştır.

\section{Uygulamaların Etkinliğinin Değerlendirilmesi}

Deneme, tesadüf parselleri deneme desenine göre beş tekrar, her tekrar için 30 adet domates tohumu kullanılmıştır. Uygulamaların etkinliği sadece patojenle bulaştırılan pozitif kontrol uygulamasıyla karşılaştırılarak değerlendirilmiştir. Tohumlar çimlendikten sonra sadece patojenle bulaştırılmış pozitif kontrol uygulamasının kotiledon yapraklarında kahverengi-siyah lekeler gözlemlendiğinde denemede gelişen bütün fideler sökülerek hastalık oranı, hastalık şiddeti ve bitki ekstraktlarının çimlenmeye etkisi değerlendirilmiştir. Tohum uygulaması olarak bitki ekstraktlarının hastalık şiddetine etkisi 0-3 skalasıly (0: kotiledon yapraklarda leke yok, 1: kotiledon yapraklarda 1 leke, 2: kotiledon yapraklarda 2-3 leke, 3: Kotiledon yapraklarda 4 ve 4 'den fazla leke) değerlendirilmiştir (Karabüyük ve ark., 2018; Cemen ve ark., 2018; Horuz ve ark., 2018).

Elde edilen veriler Tawsend-Heuberger formülüne göre hastalık şiddetinin \%'si belirlenmiştir. Bitki ekstraktlarının tohum uygulaması olarak hastalık şiddetine etki \%'si Abbott formülüyle (\% etki $=$ (kontroluygulama/kontrol) x100) hesaplanmıştır (Karman, 1971). Yapılan hesaplamadan sonra, ortalama hastalık yüzdesi saptanmış ve açı değerleri alınarak ANOVA istatistik programında LSD çoklu karşılaştırma testinde $P \leq 0,05$ önem düzeyine göre uygulamalar arasındaki fark saptanmıştır. İstatistiki olarak aynı grupta yer alan uygulamalar aynı harfle belirtilmiştir.

\section{Farklı Bitki Ekstraktlarının Yeşil Aksamdaki Hastalığa Etkisi}

$\mathrm{Bu}$ denemelerde bakteriyel patojene karş1 dört farklı bitki ekstraktıyla (A. sativum, E. camaldulensis, O.onites ve $Z$. officinale) çalışılmıştır. Deneme, tesadüf parselleri deneme desenine göre 5 tekrarlı ve her tekrarda 5 bitki olacak şekilde kurulmuştur. Her uygulama için 3-5 yapraklı dönemde (15-20 cm boyda) 25 domates fidesi olmak üzere kurulmuştur.

Hazırlanan ekstraktlar, domates bitkilerinin yeşil aksamına bir el pülverizatörüyle püskürtülerek ve kökler daldırılarak iki farklı şekilde uygulanmıştır. Yeşil aksam püskürtmelerinde uygulamaların birinde önce patojen inokulasyonu yapılmış, bundan 24 saat sonra bitki ekstraktı uygulanarak ekstraktların hastalığa karşı tedavi edici yeteneği araştırılmıştır (Goel ve Paul, 2014). Diğer bir uygulamada ise önce bitki ekstraktı yapraklara püskürtülerek uygulanmış, ardından 24 saat sonra patojen bulaştırılarak ekstraktların hastalığa karşı koruyucu özelliğinin olup olmadığı incelenmiştir (Altundağ, 2007; Alemu ve ark., 2013; Quattrucci ve ark., 2013). Üçüncü uygulamada ise domates fideleri saksılara şaşırtılmadan önce kökleri 15 dakika bitki ekstraktlarına daldırılmış üç gün sonra patojen bulaştırılarak ekstraktların bitkide dayanıklılı̆̆ı uyarıcı etkisi araştırılmıştır (Goel ve ark., 2017). Dayanıklılığı uyarıcı etkisi olan ISR-2000 adlı ticari bitki aktivatörü karşılaştırma materyali olarak kullanılmıştır. Bütün uygulama şekillerinde pozitif kontrol olarak domates fidelerine sadece patojen bakteri inokule edilmiş, negatif kontrol olarak da steril su uygulaması yapılmıştır. Uygulamalar bitkinin stomalarının açık olduğu günün erken saatlerinde yapılmıştır. Denemede yer alan uygulamalar aşağıda verilmiştir.

- Yeşil aksama önce patojen inokulasyonu 24 saat sonra ekstrakt püskürtme (Tedavi Edici Etki)

- Domates yapraklarına ekstrakt püskürtme 24 saat sonra patojen inokulasyonu (Koruyucu Etki), 
- Domates fide kökleri dikimden önce bitki ekstraktlarına daldırma üç gün sonra patojen inokulasyonu (Dayanıklılı̆̆ı Uyarıcı Etki)

- Patojen bakteri inokule edilmiş bitkiler (Pozitif Kontrol)

- Steril su uygulanmış bitkiler (Negatif Kontrol)

Pseudomonas syringae pv. tomato'nun yaprak patojeni olması nedeniyle $10^{6}$ hücre/ml yoğunlukta hazırlanan patojne süspansiyonu bir el pülverizatörüyle püskürtülerek bitkiler inokule edilmiştir.

Bitkiler günlük olarak kontrol edilmiş ve hastalık belirtileri pozitif kontrolde gözlemlendikten sonra deneme değerlendirilmiştir. Pst ile bulaştırılmış bitkilerin her birinden üç yaprak alınarak çalışma kapsamında geliştirilen 0-5 skalasıyla (0: hastalık belirtisi yok; 1: yaprak alanının \%1-15 lekeli; 2: yaprak alanının \%16-30 lekeli; 3: yaprak alanının \%31-45 lekeli; 4: yaprak alanının \%46-60 lekeli; 5: yaprak alanının \%61'den fazlası lekeli) değerlendirilmiştir (Şekil 2).

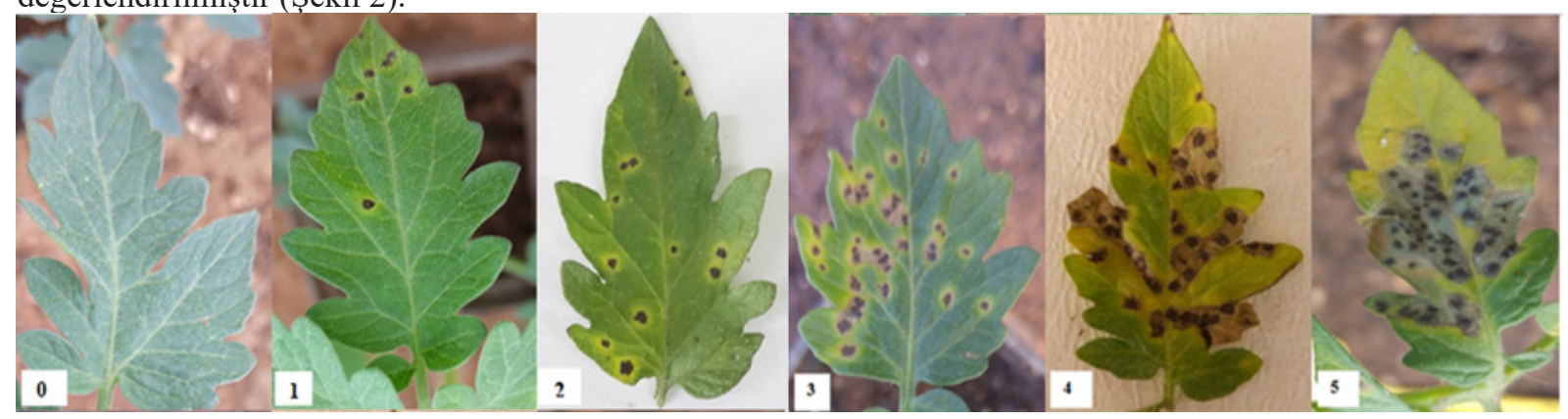

Şekil 2. Saksı denemeleri için kullanılan 0-5 skalası

Figure 2. 0 to 5 scales for pot experiments

\section{Bulgular}

Farklı Bitki Ekstraktlarını Pst'ye Antibakteriyel Etkisi ve Minimum Engelleme Konsantrasyonlarının

\section{Belirlenmesi}

Yirmi dokuz farklı bitki ekstraktının Pst'ye antibakteriyel etkisini saptamak amaciyla in vitro'da yapilan çalışmada pozitif kontrol olarak kullanılan streptomisin antibiyotiğinde $9.2 \mathrm{~mm}$ engelleme zonu saptanırken, A. sativum'da $3 \mathrm{~mm}, C$. sativum'da $13.0 \mathrm{~mm}$ ve E. camaldulensis' da $13.6 \mathrm{~mm}$ engelleme zonu geliştirdikleri kaydedilmiştir.

Denemelerde kullanılan bitki ekstraktlarının $P$ st'yi minimum engelleme konsantrasyonlarının belirlendiği çalışmada E. camaldulensis'de $3.75 \mu \mathrm{l} / \mathrm{ml}$, A. sativum'da $4.25 \mu \mathrm{l} / \mathrm{ml}$, C. sativum ve $O$. onites' $\mathrm{de}>128 \mu \mathrm{l} / \mathrm{ml}$ dozunda olduğu saptanmıştır.

\section{Farklı Bitki Ekstraktlarının Tohum Uygulaması Olarak Domates Bakteriyel Benek Hastalığına Etkisi}

Altı farklı bitki ekstraktı Pst ile bulaşık tohumlara uygulandığında, Domates Bakteriyel Benek Hastalı̆̆ \%8.8100 oranında baskılanmıştır. Hastalık şiddetinde ise ortalama \%21.5-100 arasında azalış belirlenmiştir. Sadece Pst bulaştırılan pozitif kontrol uygulamasında hastalık oranı \%65 olarak kaydedilmiştir. Negatif kontrol uygulaması olarak sadece suya daldırılan tohumlardan gelişen bitkilerde herhangi bir hastalık saptanmamıştır. Negatif kontrol ile karşılaştırılan çimlenme denemesinde, hiçbir uygulama tohumların çimlenme yeteneğine olumsuz bir etki yapmamış ve tüm uygulamalar steril su (negatif kontrol) uygulamasıyla aynı istatistiki grupta yer almıştır (Tablo 2). 
Tablo 2. Domates tohumlarına uygulanan bitki ekstraktlarının Pst’nin neden olduğu Domates Bakteriyel Benek Hastalığına etkisi

Table 2. The effect of plant extracts as seed treatment on Tomato Bacterial Speck Disease caused by Pst

\begin{tabular}{|c|c|c|c|c|c|c|c|c|}
\hline Uygulamalar & \multicolumn{2}{|c|}{ Hastalık Çıkışı (\%) } & \multirow{2}{*}{$\begin{array}{l}\% \text { Etki } \\
100.0\end{array}$} & \multicolumn{2}{|c|}{$\begin{array}{l}\text { Hastalık Şiddeti } \\
(\%)\end{array}$} & \multirow{2}{*}{$\begin{array}{l}\% \text { Etki } \\
100.0\end{array}$} & \multicolumn{2}{|c|}{ Çimlenme Oranı $(\%)^{* *}$} \\
\hline Allium sativum & 0.0 & $a^{*}$ & & 0.0 & $\mathrm{a}$ & & 73.3 & $\mathrm{a}$ \\
\hline Origanum onites & 10.7 & a & 83.4 & 7.3 & a & 84,3 & 72.7 & $\mathrm{a}$ \\
\hline Eucalyptus camaldulensis & 45.2 & $\mathrm{~b}$ & 29.9 & 28.0 & $\mathrm{~b}$ & 40.0 & 80.0 & $\mathrm{a}$ \\
\hline O.vulgare subsp. hirtum & 50.8 & $\mathrm{~b}$ & 21.3 & 31.3 & bc & 32.9 & 70.0 & a \\
\hline Zingiber officinale & 39.9 & $\mathrm{~b}$ & 38.1 & 27.3 & $\mathrm{~b}$ & 41.5 & 70.7 & $\mathrm{a}$ \\
\hline Coriandrum sativum & 58.8 & $\mathrm{~cd}$ & 8.8 & 36.7 & $\mathrm{c}$ & 21.5 & 68.0 & a \\
\hline Kontrol & 64.5 & $\mathrm{~d}$ & & 46.7 & $\mathrm{~d}$ & & 72.0 & $\mathrm{a}$ \\
\hline
\end{tabular}

*) Sütun içerisinde farklı harfi içeren ortalamalar LSD (0.05) testine göre farklıdır

\section{Farklı Bitki Ekstraktlarının Yeşil Aksamdaki Domates Bakteriyel Benek Hastalığına Etkisi}

Dört bitki ekstraktı (A. sativum, E. camaldulensis, O. onites ve Z. officinale) domates bitkilerinin yeşil aksamına püskürtüldüğünde, $P$ st'nin neden olduğu Domates Bakteriyel Benek Hastalığının şiddetinde \%95.1-99.1 arasında değişen oranlarda azalma tespit edilmiştir. Sadece Pst bulaştırılan pozitif kontrol uygulamasında hastalık şiddetinin ortalama \%53.3 iken, yeşil aksama bitki ekstraktları uygulandığında hastalık şiddeti \%0.5-2.6 arasında olduğu belirlenmiştir. İstatistiki olarak incelendiğinde, yeşil aksama bitki ekstraktı uygulamaları pozitif kontrol uygulamasından farklı ve etkili bulunmuştur. Tüm uygulamalar kontrolden farklı tek bir grup oluşturmuştur (Tablo 3.).

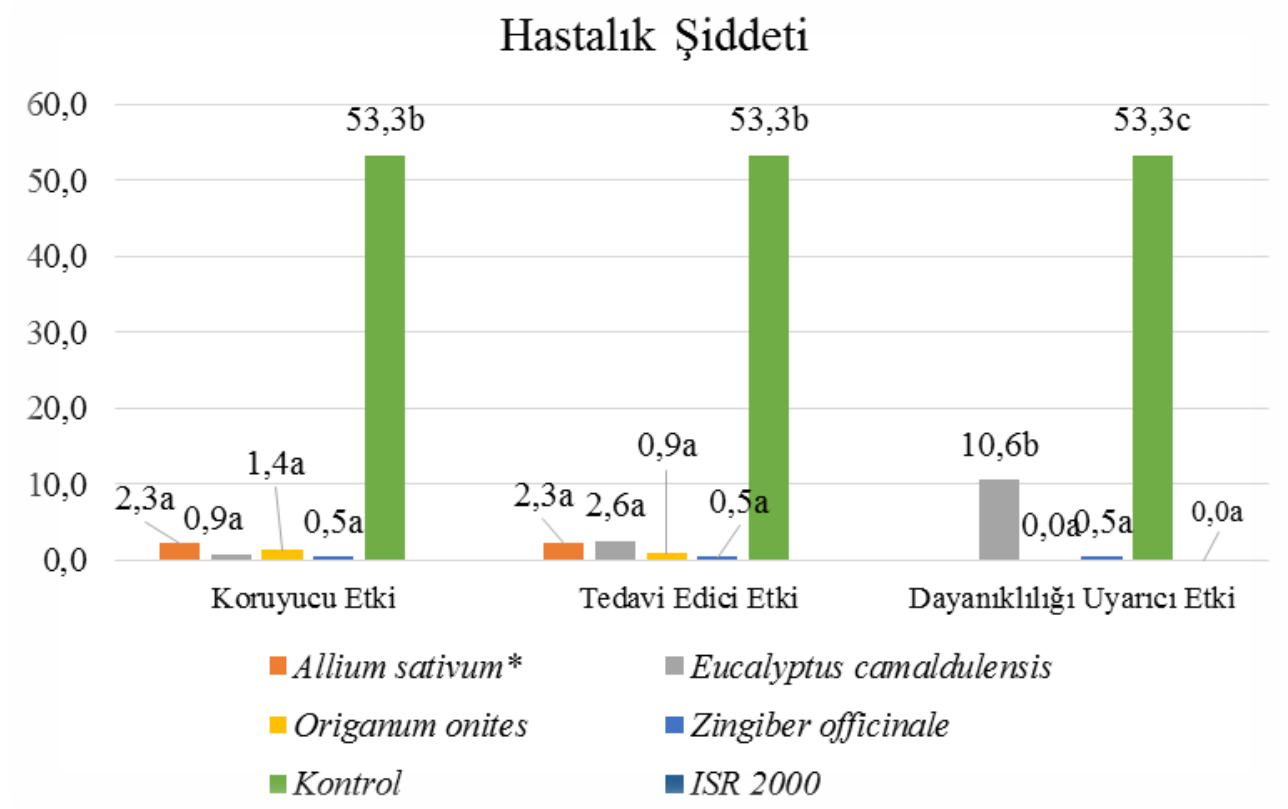

*: Dayanıklılık Uyarıcı Etki'de Allium sativum fitotoksik olmuştur

Figure 3. Bitki ekstraktlarının Pst'nin neden olduğu Domates Bakteriyel Benek Hastalığına etkisi

Şekil 3. Effect of plant extracts on tomato bacterial speck disease caused by Pst

Bitki ekstraktlarının patojen bulaşmasından önce veya sonra uygulanmaları hastalığın baskılanmasında bir fark yaratmamıştır. Diğer bir ifadeyle, Pst domates yapraklarına bulaştıktan 24 saat sonra A. sativum, E. camaldulensis, $O$. onites ve Z. officinale ekstraktları domates yapraklarına uygulandığında Bakteriyel Benek Hastalığı gayet başarılı bir şekilde engellenmiş ve tedavi edici özellikte olduğu saptanmıştır. Benzer şekilde bu dört bitki ekstraktı domates yapraklarına püskürtüldükten 24 saat sonra patojen bakteri Pst yapraklara bulaştığında hastalık yine etkili 
bir şekilde engellenmiş ve uygulamanın koruyucu etkiye de sahip olduğu belirlenmiştir.

Fide kökleri dikim öncesi dört bitki ekstraktına daldırıldığında, O. onites ve Z. officinale ekstraktları hastalık şiddetinde \%99.1-100 arasında değişen oranlarda azalışa neden olmuştur. Çalışmada karşılaştırma materyali olarak kullanılan ISR-2000 adlı ticari preparat da O.onites uygulaması gibi Bakteriyel Benek Hastalığını tamamen baskılamıştır. E. camaldulensis ekstraktına daldırma ise hastalık şiddetini \%80.1 oranında baskılamıştır. E. camaldulensis, $O$. onites ve Z.officinale ekstraktları bitkide dayanıklılığı uyararak hastalığı engellediği belirlenmiştir. Ancak A. sativum ekstraktına domates fidelerinin köklerini daldırmak bitki için toksik olmuş ve uygulaması görmüş 25 fideden sadece üçü canlı kalabilmiş diğerleri kuruyarak ölmüştür.

\section{Tartışma}

Günümüzde tarım yapılan alanlardaki en önemli sorunlardan biri, yetiştiriciliği yapılan ürünlerin kalitesinde ve miktarında azalmaya neden olan hastalıklardır. Hastalık mücadelesinde kullanılan sentetik kimyasalların maliyeti, farklı bitkilerdeki fitotoksite sorunu (Cai ve ark., 2017), uygulanan kimyasallara karşı direnç problemi (Milijašević ve ark., 2009; Yang ve ark., 2013), bu kimyasalların insan ve çevre sağlığına olumsuz etkileri (Kotan ve ark., 2014; La Torre ve ark., 2018) ve tüketicilerin organik ürünlere olan eğilimi gibi nedenlerle hastalık yönetiminde farklı stratejiler (Kaya, 2017) geliştirmek bir zorunluluk olarak karşımıza çıkmaktadır.

$\mathrm{Bu}$ çalışmanın in vitro koşullardaki sonuçları incelendiğinde, en güçlü antibakteriyel etki Allium sativum ekstraktından elde edilmiştir. Farklı çalışmalar incelendiğinde insan ve bitki patojenlerine karşı antibakteriyel etkisi en fazla araştırılan bitki türlerinden biri Allium sativum'dur. Allium sativum'un başarısı içerisinde bulunan kükürt ihtiva eden bileşiklerden, uçucu yağlardan (alicin, alliin ve ajoene), enzimlerden, karbonhidratlardan, minerallerden, aminoasitlerden, biyoflavonoidlerden, vitaminlerden, beta karoten gibi 200’ü aşkın kimyasal maddeden kaynaklanmaktadır (Faydaoğlu ve Yücel, 2014). Allium sativum ekstraktının Pst'ye karşı antibakteriyel etkisi çalışmamızda kanıtlanmıştır. In vitro da Allium sativum ekstraktı Pst'ye karşı düşük antibakteriyel etki oluştururken, saksı denemelerinde tam tersi bir durumla karşılaşılmıştır. Saksı çalışmalarında Allium sativum ekstraktı yeşil aksama uygulandığında Pst'nin neden olduğu hastalığ $\% 96$ oranında baskılamıştır. In vitro ve in vivo denemelerdeki uyumsuzluk fitopatoloji çalışmalarında yaygın olarak karşılaşılan bir durumdur (Goel ve ark., 2017) ve bu durumla burada da karşılaşılmıştır. Allium sativum antibakteriyel etkisinin yanı sıra, bitkide sistemik dayanıklılık mekanizmasını da uyarmaktadır (Curtis ve ark., 2004; Slusarenko ve ark., 2008). Ancak Allium sativum ekstraktı domates köklerine uygulandığında fitotoksiteye neden olmuş ve fideler ölmüştür. Özellikle içerisinde barındırdığı uçucu yağların buna neden olabileceği düşünülmüştür.

In vitro ve in vivo çalışmalarının uyumsuzluğunu gösteren bir sonuçla Origanum onites ile yapılan çalışmalarda da karşılaşılmıştır. Origanum onites in vitro petri denemelerinde herhangi bir antibakteriyel madde üretmezken, in vivo denemelerde gayet başarılı olduğu saptanmıştır. Benzer şekilde Azadiracthta indica (Goel ve Paul, 2014) ve Tagetes erecta (Goel ve ark., 2017) ekstraktları Pst'ye petride etkisizken, bitkide çeşitli enzimleri (peroksidaz, fenil amonyak liyaz ve polifenol oksidaz aktivitesini) aktive ederek hastalığ bitkide baskılamıştır. Bu durum bitki ekstraktlarının sadece antibakteriyel aktiviteyle değil, farklı mekanizmalarla da hastalığı baskıladığı düşüncesini akla getirmektedir. Bitki ekstraktlarının dayanıklılığı uyarıcı etkileri farklı çalışmalarla da ortaya konmuştur (Curtis ve ark., 2004; Slusarenko ve ark., 2008; Baştaş, 2015; Goel ve ark., 2017). Bu çalışmada Origanum onites'in MIC değeri de $>128 \mu \mathrm{l} / \mathrm{ml}$ olarak belirlenmiş ve antibakteriyel aktivitesi düşük olarak değerlendirilmiştir. Origanum onites'in ile yapılan in vivo çalışmalarda Pst'nin tohumdan dezenfeksiyonunda \%83, bitkide hastalığı baskılama yeteneği \%93'ün üzerinde olmuştur. Origanum onites petride Pst gelişimini baskılayamazken bitkide hastalık gelişimini gayet yüksek oranda baskılaması bitkide dayanıklılık mekanizmasını uyardığı fikrini akla getirmiştir. Benzer şekilde Kotan ve ark (2014)'da Origanum onites'in domateste dayanıklılığı uyardığından bahsetmektedir. Origanum onites' in bitkide aktive ettiği maddelerin neler olduğu gelecekte araştırılmalıdır.

Allium sativum'un MIC değeri Pst için $4.25 \mu \mathrm{l} / \mathrm{ml}$ olarak tespit edilmiştir. MIC ile ilgili daha önce yapılan çalışmalar incelendiğinde, benzer şekilde Xanthomonas axonopodis pv. citri ve Pseudomonas solanacearum için de $40 \mathrm{mg} / \mathrm{ml}$ (Jeyaseelan ve ark., 2011) oranı bulunmuştur.

$\mathrm{Bu}$ çalışmada bitki ekstraktları domates tohumlarına uygulanmış, ayrıca fide döneminde yeşil aksama püskürtülmüş veya fideler toprağa şaşırtılmadan kökleri bitki ekstraktlarına daldırılmıştır. Etkinlik açısından tohum uygulamalarıyla yeşil aksama uygulamaları arasında farklılıklar görülmüştür. Pst'nin neden olduğu bakteriyel benek hastalığı tohum uygulamalarıyla çok daha başarılı şekilde baskılanmıştır. Pst gibi tohum kökenli bakteriyel hastalıkların mücadelesinde ilk adım hastalıksız üretim materyali kullanmak olmalıdır (Öcal, 2015). Domates tohumlarında uzun süre yaşamını sürdüren $P s t$ tohumun çimlenmesi esnasında popülasyonunu arttırır ve 
tohum kabuğundan gerçek yapraklara bulaşarak hastalığın yayılmasına neden olur (Aysan ve ark., 2005). Tohum kabuğunda lokalize olan Pst mücadelesinde tohum uygulamaları gayet başarılı sonuç vermektedir (Horuz ve ark., 2018). Benzer çalışmalarda (van der Wolf ve ark., 2008; Verma ve Agrawal, 2015 Verma ve Agrawal, 2017; Umarusman ve ark., 2018) olduğu gibi, tohuma çeşitli bitki ekstraktlarını uygulamanın başarısı bu çalışmayla da ortaya konmuştur.

Tüm sonuçlar dikkate alındığında, Pst'nin neden olduğu Domates Bakteriyel Benek Hastalığının entegre yönetiminde, bitki ekstraktlarının tohuma, köke veya yeşil aksama uygulanabileceği bu çalışmayla gösterilmiştir. Başarılı bulunan bitki ekstraktlarının diğer domates bakteriyel patojenlerine antibakteriyel etkisinin araştırılması faydalı olacaktır. Bu çevre dostu bitkisel kökenli antimikrobiyal maddeler ticarileştirilmeden önce optimum ekstraksiyon yöntemi ve formülasyonu, etkili doz miktarlarının tespiti ve fitotoksiteyi ortadan kaldıracak yöntemlerin araştırılması gereklidir.

\section{Teşekkürler}

Bu çalışma Çukurova üniversitesi BAP birimi tarafından FDK 2015-4071 kodlu projeyle desteklenmiştir. 


\section{Kaynakça/References}

Agrawal, K., Sharma, D.K., and Jain, V.K., 2012. Seed-Borne Bacterial Diseases of Tomato (Lycopersicon esculentum Mill.) and Their Control Measures: A Review. International Journal of Food, Agriculture and Veterinary Sciences 2 (2): 173-182p.

Alemu, D., Lemessa, F., Wakjira, M., and Berecha, G., 2013. Antibacterial Activity of Some Invasive Alien Spesies Exrracts against Tomato (Lycopersicon esculentum Mill) Bacterial Wilt Caused by Ralstonia solanacearum (Smith). Plant Pathology Journal, 12 (2): 61-70p.

Altundağ, Ş., 2007. Labiatae Familyasına Ait Bazı Endemik Türlerin Önemli Bitki Patojeni Bakteriler Üzerine Antimikrobiyel Etkisinin Araştırılması. Gazi Üniversitesi, Biyoloji Bölümü, Yüksek Lisans Tezi.

Anonim,2017.http://www.megep.meb.gov.tr/mte_program_modul/moduller_pdf/Patlicangil\%20Sebzeleri\%20 Yeti\%C5\%9Ftiricili\%C4\%9Fi\%201.pdf. (Erişim Tarihi:18.08.2018).

Anonim,2018.http://www.megep.meb.gov.tr/mte_program_modul/moduller_pdf/Antibiyotik\%20Duyarl\%C4\%B11\%C4\%B1k\%20Testi.pdf. (Erişim Tarihi: 2906 2018).

Arshad, W., Haq, I., Waheed, T.M., Mysore, K.S., and Mirza, B., 2014. Agrobacterium-Mediated Transformation of Tomato with a rolB Gene Results in Enhancement of Fruit Quality and Foliar Resistance against Fungal Pathogens. PLoS ONE 9 (5) e96979.

Aysan, Y., Mirik, M., Sahin, F., and Çetinkaya-Yıldız, R., 2004. Outbreak of Bacterial Speck Disease in a Nursery in The Eastern Mediterranean Region of Turkey. $3^{\text {rd }}$ Balkan Symposium on Vegetables \& Potatoes, 6-10 September, 2004, Bursa Turkey. Acta Horticulturae 729: 441443 s.

Aysan, Y., Mirik, M., Çetinkaya-Yıldız, R., ve Küsek, M., 2005. Pseudomonas syringae pv. tomato'nun Yayılmasına Tohum Kökenli İnokulumun Rolü, Türkiye II. Tohumculuk Kongresi 9-11 Kasım 2005, Adana, 353s.

Aysan, Y., ve Saygılı, H., 2008. Domates Bakteriyel Benek Hastalığı. (H. SAYGILI, F. ŞAHİN, Y. AYSAN Editörler) Bitki Bakteri Hastalıkları, Meta Basim Matbaacilik Hizmetleri, İzmir, 123-126s.

Balestra, G.M., Heydari, A., Ceccarelli, D., Ovidi, E., and Quattrucci, A., 2009. Antibacterial Effect of Allium sativum and Ficus carica Extracts on Tomato Bacterial Pathogens. Crop Protection, 28: 807-811p.

Basim, H., Basim, E., Yilmaz, S., Dickstein, E.R., and Jones, J.B., 2004. An Outbreak of Bacterial Speck Caused by Pseudomonas syringae pv. tomato on Tomato Transplants Grown in Commercial Seedling Companies Located in The Western Mediterranean Region of Turkey. Plant Disease, 88: 1050p.

Baydar, H., 2009. Sekonder Metabolitlerin Önemi.Tıbbi ve Aromatik Bitkiler Bilimi ve Teknolojisi. Süleyman Demirel Üniversitesi Yayın No: 51 Ziraat Fakültesi, SDÜ Basım Evi, Isparta. 45-63s.

Baştaş, K.K., 2015. Determination of Antibacterial Efficacies of Plant Extracts on Tomato Bacterial Speck Disease. The Journal of Turkish Phytopathology, 44 (1-3): 1-10p.

Cai, J., Wang, M., Zhao, X., Zhang, Y., and Yuan, X., 2017. Antimicrobial Activity of Laminaria japonica Extract against Bacterial Canker of Tomato Disease Agent Clavibacter michiganensis subsp. michiganensis. Journal of Applied anf Food Quality 90: 183-190.

Cemen, A., Aysan, Y., Horuz, S., and Sayg1l1, H., 2018. Biological Control of Tomato Bacterial Speck Disease Using Bacteriophages. Integrated Control in Protected Crops, Temperature Climate, IOBC, WPRS Bulletin. 124: 146p.

Curtis, H., Noll, U., Störmann, J., and Slusarenko, A.J., 2004. Broad-Spectrum Activity of The Volatile Phytoanticipin Allicin in Extracts of Garlic (Allium sativum L.) Against Plant Pathogenic Bacteria, Fungi and Oomycetes. Physiological and Molecular Plant Pathology, 65: $79-89$.

Çetinkaya-Yıldız, R., ve Aysan, Y., 2014. Domates Bakteriyel Solgunluk Hastalığının Bitki Büyüme Düzenleyici Kök Bakterileri ile Biyolojik Mücadelesi. Türkiye Biyolojik Mücadele Dergisi, 5 (1): 9-22s.

Dadasoglu, F., Aydin, T., Kotan, R., Cakir, A., Ozer, H., Kordali, S., Cakmakci, R., Dikbas, N., and Mete, E., 2011. Antibacterial Activities of Extracts and Essential Oils of Three Origanum Species Against Plant Pathogenic Bacteria and Their Potential Use as Seed Disinfectants. Journal of Plant Pathology, 93 (2): 271-282p

Erlen, F., 2000. Bitki Kökenli Bileşiklerin Böcek ve Akarlarla Mücadelede Kullanılma Potansiyeli Üzerinde Araştırmalar. Doktora Tezi. Akdeniz Üniversitesi, Ziraat Fakültesi, Bitki Koruma Anabilim Dalı.

Farimaz, A., Horuz, S., ve Aysan, Y., 2014. Çeșitli Bitki Aktivatörleri ve Ticari Gübrelerin Karpuz Bakteriyel Meyve Lekesi Hastalığına Etkisi. Türkiye Biyolojik Mücadele Dergisi, 5 (1): 31-38p.

Faydaoğlu, E. ve Yücel M.R., 2014. Geleneksel Tedavide Sarımsak (Allium sativum) Önemi ve Kullanım Alanları, II. Tıbbi ve Aromatik Bitkiler Sempozyumu, 23-25 Eylül 2014, 153. Ganiyu, A.S., Popoola, A.R., Owolade, O.F., and Fatona, K.A., 2017. Control of Common Bacterial Blight Disease of Cowpea (Vigna unguiculata [L.] Walp) with Certain Plant Extracts in Abeokuta, Nigeria. Journal of Crop Improvement, 31:3, 280-288

Goel, N., and Paul, P.K., 2014. Neem Fruit Extract Induces Peroxidase and Lipoxygenase in Tomato. Asian Journal of Biological and Life Sciences, 3 (3): 189-194p.

Goel, N., Anukrati, K., and Paul, P.K., 2017. Biocontrol of Bacterial Speck of Tomato by Aqueous Extract of Tagetes erecta. Journal of Plant Protection Research 57 (4).

Horuz, S., Ocal, A., and Aysan, Y., 2018. Efficacy of Hot Water and Chemical Seed Treatments on Bacterial Speck of Tomato in Turkey. Fresenius Environmental Bulletin, 27 (5): 3185-3190p.

Jones, J.B., Zitter, T.A, Momol, T.M., and Miller, S.A., 2014. In: Compendium of Tomato Diseases and Pests, Second Edition, APS Press, Minnesota, USA, 50-70p.

Jeyaseelan, E.C., Pathmanathan, M.K. and Jeyadevan J.P., 2011. Inhibitory Effect of Different Solvent Extracts of Vitex negundo L. and Allium sativum L. on Phytopathogenic Bacteria. Archives of Applied Science Research, 3 (1): 1-8p. 
Kamba, A.S, and Hassan, G.L., 2010. Phytochemical And Microbial Screening of Parkinsonıa aculeata L. Leaves. International Journal of Drug Development \& Research, 2: 1p.

Karabüyük, F., Kirli, M.M., Horuz, S. ve Aysan, Y., 2014. Adana'da Domateslerde Fidelik ve Tarlada Sorun Olan Tohum Kökenli Bakteriyel Hastalıklar. 5. Uluslararası Katılımlı Tohumculuk Kongresi, 19-23 Ekim 2014, Diyarbakır, 682-684s.

Karabüyük, F., and Aysan, Y., 2018. Aqueous Plant Extracts as Seedtreatments on Tomato Bacterial Speck Disease. Proceeding of The V. International Symposium on Tomato Diseases: ,perspectives and future directions in Tomato Protection. Acta Horticulture, 1207: $193-196$.

Karman, M., 1971. Bitki Koruma Araștırmalarında Genel Bilgiler. Denemelerin Kurulușu ve Değerlendirme Esasları, T.C. Tarım Bakanlığı Zirai Mücadele ve Zirai Karantina Genel Müdürlüğü Yayınları, 279s.

Kaya, C., 2017. Organik Tarımda Bitki Koruma Ürünlerinin Seçimi ve Doğru Kullanımı, Zirai Mücadele Araştırma Enstitüsü Müdürlüğ̈// DIYARBAKIR.

Kotan, R., Dadasoglu, F., Kordali, S., Cakır, A., Dikbas, N., and Cakmakc1, R., 2007. Antibacterial Activity of Essential Oils Extracted From Some Medicinal Plants, Carvacrol and Thymol on Xanthomonas axonopodis pv. vesicatoria (Doidge) dye Causes Bacterial Spot Disease on Pepper and Tomato. Journal of Agricultural Technology 3(2): 299-306p.

Kotan, R., Dadasoğlu, F., Karagöz, K., Cakir, A., Ozer, H., Kordali, S., Cakmakci, R., Dikbas, N., 2013. Antibacterial Activity of The Essential Oil and Extracts of Satureja Hortensis Against Plant Pathogenic Bacteria and Their Potential Use as Seed Disinfectants. Scientia Horticulturae, 153: 34-41p.

Kotan, R., Cakir, A., Ozer, H., Kordali, S., Cakmakci, R., Dadasoglu, F., Dikbas, N., Aydın, T., and Kazaz, C., 2014. Antibacterial Effects of Origanum onites against Phytopathogenic Bacteria: Possible Use of The Extracts from Protection of Disease Caused by Some Phytopathogenic Bacteria. Scientia Horticulturae, 172: 201-220.

Kozak, S. ve Erkılıç, A., 2014. Bazı Bitki ekstraktlarının Fusarium oxysporum f. sp. melongenae Üzerine Etkilerinin Belirlenmesi. Türkiye V. Bitki Koruma Kongresi, 3-5 Şubat 2014, Antalya, 237s.

La Torre, A., Lovino, V., and Caradonia, F., 2018. Copper in Plant Protection: Current Situation and Prospects. Phytopathologia Mediterranea, 57 (2): $201-236$

Lelliott, R.A., and Stead, D.E., 1987. Methods for The Diagnosis of Bacterial Diseases of Plants. Methods in Plant Pathology, (T. F. Preece, Series editor), Volume 2, Published on behalf of the British Society for Plant Pathology by Blackwell Scientific Publications, Oxford, UK., 219p.

Mangamma, P., and Speeramula, A., 1981. Garlic Extract Inhibitory to Growth of Xanthomonas campestris pv. vesicatoria. Indian Phytopathology, 44: 372p.

Mbega, E.R., Mabagala, R.B., Wulff, E.G., and Mortensen, C.N., 2011. Plant Extracts and essential Oils in Seed Treatment. Production of Healthy Tomato Transplants Danish Seed Health Centre for Developing Countries, University of Copenhagen.

Mc Manus P.S., Stockwell, V.O., Sundin, G.W., and Jones, A.L., 2002. Antibiotic Use in Plant Agriculture, Annual Review of Phytopathology, 40: $443-65 \mathrm{p}$

Milijašević, S., Todorović, B., Potočnik, I., Rekanović, E., and Stepanović, M., 2009. Effects of Copper-Based Compounds, Antibiotics and A Plant Activator on Population Sizes and Spread of Clavibacter michiganensis subsp. michiganensis in Greenhouse Tomato Seedlings. Pesticides Phytomedicine Belgrade Journal, 24: 19-27.

Miller, S.A., and Jones, J.B., 2014. Bacterial Speck. (J.B Jones, T.A Zitter, T.M. Momol and S.A. Miller, Edition) In: Compendium of Tomato Diseases and Pests, Second Edition, The American Phytopathological Society, 54-55p.

Mirik, M. ve Aysan Y., 2002. Tohum Kökenli Xanthomonas cmpestris pv. vesicatoria Üzerine Çeşitli Bitki Ekstraktlarının Etkisi. Türkiye I. Tohumculuk Kongresi,11-13 Eylül 2002, İzmir. 333-338s.

Murthy. K.N., Uzma, F., Soumya. K., and Srinivas, C., 2015. Antibacterial Activity of Neem (Azadirachta indica) Plant Extracts against Bacterial Wilt of Tomato Caused by Ralstonia solanacearum. International Journal of Research in Agricultural Sciences, 2, (5): 23483997 p.

Öcal, A., 2015. Farklı Tohum Uygulamalarının Domates Bakteriyel Kara Leke Hastalığına Etkisi. Yüksek Lisans Tezi, Çukurova Üniversitesi, Bitki Koruma Anabilim Dalı.

Silva, R.F., Pascholati, S.F., and Bedendo, I.P., 2013. Induced Resistance in Tomato Plants to Clavibacter michiganensis subsp. michiganensis by Lentinula edodes and Agaricus subrufescens (syn. Agaricus Brasiliensis). Journal of Plant Pathology, 95 (2): 285-297p.

Soykan, Ö., ve Aysan, Y., 2011. Bazı Bitki Aktivatörleri ile Organik ve İnorganik Gübrelerin Domates Bakteriyel Kanser ve Solgunluk Hastalığına Etkisi. Türkiye IV: Bitki Koruma Kongresi Bildirileri, 28-30 Haziran 2011, Kahramanmaraş, 317s.

Slusarenko, A.J., Patel, A., and Portz, D., 2008. Control of Plant Diseases by Natural Products: Allicin From Garlic as a Case Study. European Journal of Plant Pathology 121: 313-322p.

Umarusman, M.A., Aysan, Y., and Özgüven, M., 2018. Investigation of The Antimicrobial Effects of Different Plant Extracts Against Pea Bacterial Leaf Blight Disease Caused by Pseudomonas syringae pv. pisi. IX International Scientific Agricultural Symposium, October 04-07, Bosnia and Herzegovina, 706p.

van der Wolf, J.M., Birnbaum, Y., van der Zouwen, P.S., and Groot, S.P.C., 2008. Disinfection of Vegetable Seed by Treatment With Essential Oils, Organic Acids and Plant Extracts. Seed Science and Technology, 36: 76-88p.

Verma, A.K., and Agrawal K., 2015. Bio-Efficacy of Some Medicinal Plant Extracts Against Pseudomonas syringae pv. pisi causing Bacterial Blight of Pea, International Journal of Pharmacology and Toxicology 5(1): 67-70p.

Verma, A.K., and Agrawal, K., 2017. In vitro Evaluation of Antibacterial Activity of Some Medicinal Plants against Xanthomonas pisi Causing Leaf Spot of Pea. International Journal of Pharmaceutical Sciences Review and Research, 45(2): 156-159p.

Yang, R., Luo, C., Chen Y., Wang G., Xu, Y., and Shen Z., 2013. Copper-Resistant Bacteria Enhance Plant Growth and Copper Phytoextraction. 
International Journal of Phytoremediation, 15 (6): 573-584.

Quattrucci, A., Ovidi, E., Tiezzi, A., Vinciguerra, V., and Balestra, G.M., 2013. Biological Control of Tomato Bacterial Speck Using Punica granatum Fruit Peel Extract. Crop Ptrotection 46: 18-22p. 